\title{
Uji daya hambat ekstrak alga coklat (Padina australis Hauck) terhadap pertumbuhan bakteri Porphyromonas gingivalis secara in vitro
}

\author{
${ }^{1}$ Dewi P. Sari \\ ${ }^{2}$ Damajanty H. C. Pangemanan \\ ${ }^{3}$ Juliatri \\ ${ }^{1}$ Kandidat Skripsi Program Studi Pendidikan Dokter Gigi Fakultas Kedokteran \\ ${ }^{2}$ Bagian Fisiologi Fakultas Kedokteran \\ ${ }^{3}$ Program Studi Pendidikan Dokter Gigi Fakultas Kedokteran \\ Universitas Sam Ratulangi Manado \\ Email: Dewipuspitasari978@yahoo.com
}

\begin{abstract}
Padina australis Hauck is one of the brown algae used as human food, cattle woof, and as antibacterial in medicine. This brown algae contains some antibacterial compounds such as alkaloid, phenol, tannin, steroid, and saponin. Periodontitis is a disease that causes infection and inflammation around tooth's supportive tissue. One of the alternatives to treat periodontitis is using the brown algae Padina australis Hauck. This study aimed to obtain the effectiveness of Padina australis Hauck to inhibit the growth of Porphyromonas gingivalis. This was an experimental study using wells with modified Kirby-Bauer method. Samples were obtained from Molas coastal areaa, sub district of Bunaken, Manado city, North Sulawesi. The samples were extracted by maceration method. Porphyromonas gingivalis was obtained from pure stock bacteria at the Microbiology Laboratory Faculty of Medicine, University of Hassanuddin Makassar. The results showed that the total diameter of inhibition zones of Padina australis Hauck extract was $91.0 \mathrm{~mm}$ from five Petri dishes with an average of $18.2 \mathrm{~mm}$. Conclusion: Padina australis Hauck extract had sttrong antibacterial effect to inhibit the growth of porphyromonas gingivalis bacteria.
\end{abstract}

Keywords: padina australis hauck, porphyromonas gingivalis, zona hambat

\begin{abstract}
Abstrak: Padina australis Hauck merupakan salah satu jenis alga coklat yang berguna sebagai makanan manusia, pakan ternak, dan antibakteri dalam bidang kesehatan. Padina australis Hauck mengandung berbagai senyawa yang bersifat antibakteri seperti alkaloid, fenol, tannin, steroid dan saponin. Periodontitis merupakan penyakit yang menyebabkan infeksi dan peradangan jaringan pendukung gigi. Salah satu alternatif untuk menanggulanginya yaitu dengan tumbuhan alga coklat (Padina australis Hauck). Penelitian ini bertujuan untuk mengetahui efektivitas Padina australis Hauck dalam menghambat pertumbuhan bakteri Porphyromonas gingivalis. Jenis penelitian ini ialah eksperimental secara in vitro dengan metode modifikasi Kirby-Bauer menggunakan sumuran. Sampel diperoleh dari pesisir pantai Molas Kecamatan Bunaken Kota Manado Sulawesi Utara dan diekstraksi dengan menggunakan metode maserasi. Porphromonas gingivalis yang digunakan dalam penelitian diperoleh dari stok bakteri murni di Laboratorium Mikrobiologi Fakultas Kedokteran Universitas Hasanuddin Makassar. Hasil penelitian menunjukkan total diameter zona hambat yang dihasilkan ekstrak Padina australis Hauck pada lima cawan Petri sebesar 91,0 mm dengan nilai rerata 18,2 mm. Simpulan: Ekstrak Padina australis Hauck memiliki efek antibakteri yang tergolong dalam katagori kuat dalam menghambat pertumbuhan bakteri Porphyromonas gingivalis.
\end{abstract}

Kata kunci: Padina australis Hauck, Porphyromonas gingivalis, zona hambat 
Penyakit periodontal banyak diderita oleh masyarakat di seluruh dunia dan mencapai $50 \%$ dari jumlah populasi dewasa. Asia dan Afrika mempunyai prevalensi dan intensitas penyakit periodontal yang lebih tinggi daripada Eropa, Amerika dan Australia. Penyakit periodontal di Indonesia menduduki urutan ke-2 dan masih merupakan masalah di masyarakat. Periodontitis dapat menjadi penyakit serius apabila tidak dilakukan perawatan secara tepat. Kebanyakan kasus, periodontitis merupakan penyebab terbesar kehilangan gigi pada orang dewasa. ${ }^{1}$

Periodontitis dapat terjadi karena adanya akumulasi plak. Mikroorganisme yang berkoloni di dalam plak akan mengeluarkan lipopolisakarida (LPS) yang dapat merusak jaringan periodontal. ${ }^{2}$ Mikroorganisme yang ditemukan pada plak menunjukkan bakteri Gram negatif tertentu pada penyakit periodontitis. Penyebab utama dari periodontitis ialah bakteri Porphyromonas gingivalis. ${ }^{3}$ Bakteri ini bersifat naerob Gram negatif dan merupakan bakteri patogen yang paling banyak ditemukan pada periodontitis. Dewasa ini banyak penelitian yang dilakukan untuk mencari obat-obatan baru yang berasal dari alam. $^{4}$

Biota laut juga dapat dimanfaatkan sebagai bahan obat yaitu antara lain alga (seaweed). Alga merupakan bagian terbesar dari plantae kingdom yang hidup di laut, dan secara morfologik dapat digolongkan thallophyta karena tidak memiliki perbedaan pada susunan morfologi seperti akar, batang, dan daun. ${ }^{5}$

Fukosantin, omega-3, glikolipid, tokoferol, peptida, terpena, fukosterol, polisakarida, florontanin, fenol, dan alkaloid saponin, tannin, steroid merupakan senyawa yang terdapat pada alga coklat. Alga coklat telah lama digunakan dalam pengobatan tradisional untuk penurun panas, gondok, gangguan ginjal, gangguan perut. Jenis alga ini menghasilkan ekstrak berupa senyawa polimer yang banyak digunakan dalam industri farmasi. ${ }^{6}$

Penelitian mengenai pemanfaatan alga coklat Padina australis Hauck sebagai antibiotik dalam pengobatan periodontitis belum banyak dilaporkan sehingga peneliti tertarik melakukan penelitian mengenai uji daya hambat ekstrak alga coklat tersebut terhadap pertumbuhan bakteri Porphyromonas gingivalis.

\section{BAHAN DAN METODE PENELITIAN}

Jenis penelitian yang dilakukan ialah eksperimental laboratorium murni secara in vitro dengan rancangan penelitian post test only control group. Penelitian ini dilaksanakan pada bulan Mei-Juni 2016. Pengambilan sampel di pesisir pantai Molas Kecamatan Bunaken Kota Manado Sulawesi Utara. Uji mikrobiologi dilakukan di Laboratorium Mikrobiologi jurusan Farmasi FMIPA Universitas Sam Ratulangi Manado.

Ekstrak Padina australis Hauck dibuat dengan cara maserasi. Metode pengujian yang digunakan dalam penelitian ini ialah metode modifikasi Kirby-Bauer dengan menggunakan sumuran. Media MHA disediakan sebanyak lima cawan petri dengan 15 buah sumur, lima sumur pertama yang sudah terbentuk pada media agar di lima cawan petri diisi dengan larutan ekstrak Padina australis Hauck yang sudah dilarutkan dengan etanol $96 \%$ sebagai kelompok intervensi, lima sumur berikutnya diisi metronidazole dengan pelarut akuades sebagai kelompok kontrol positif dan lima sumur lainnya diisi dengan akuades sebagai kelompok kontrol negatif. Cawan Petri selanjutnya diinkubasi dalam inkubator pada suhu $37^{\circ} \mathrm{C}$ selama 24 jam. Setiap cawan Petri berisi satu sumur kelompok intervensi, satu sumur kelompok kontrol positif dan satu sumur kelompok kontrol negatif.

Media brain heart infusion broth (BHIB) digunakan untuk suspense uji bakteri yang disamakan dengan standar kekeruhan larutan baku Mcfarland terdiri atas dua komponen yaitu larutan $\mathrm{BaCl}_{2} \quad 1 \%$ dan $\mathrm{H}_{2} \mathrm{SO}_{4} 1 \%$. . Larutan baku McFarland 0,5 ekuivalen dengan suspensi sel bakteri dengan konsentrasi $1,5 \times 10^{8} \mathrm{CFU} / \mathrm{mL}$. Kekeruhan ini yang akan dipakai sebagai 
standar suspensi bakteri uji. ${ }^{7}$ Kontrol positif dibuat dengan menggunakan bubuk antibiotik metronidazole, yang dicampur dengan pelarut akuades hingga homogen. Akuades digunakan sebagai kontrol negatif.

Pengamatan dilakukan setelah 24 jam masa inkubasi. Zona hambat yang terbentuk di sekitar sumur diukur diameter vertikal dan diameter horizontal dengan satuan milimeter $(\mathrm{mm})$ menggunakan jangka sorong. Hasil pengukuran diameter zona hambat diklasifikasikan berdasarkan respon hambatan pertumbuhan menurut David and Stout. $^{8}$

\section{HASIL PENELITIAN}

Pertumbuhan bakteri paska inkubasi terlihat daerah terang atau bening disekitar lubang sumur, yang artinya terdapat pembentukan zona hambat pada sumur kesatu yang ditetesi ekstrak Padina australis Hauck dan pada sumur kedua yang ditetesi antibiotik metronidazole. Zona hambat Padina australis Hauck dan antibiotik tampak jelas berupa daerah bening disekitar lubang sumur. Pada sumur ketiga yang ditetesi akuades tidak terlihat zona hambat, karena akuades tidak memiliki efek bakterisida dan merupakan larutan yang netral. Zona hambat yang terbentuk dalam penelitian ini dapat dilihat pada Gambar 1. Hasil pengukuran diameter zona hambat Padina australis Hauck dapat dilihat pada Tabel 1.

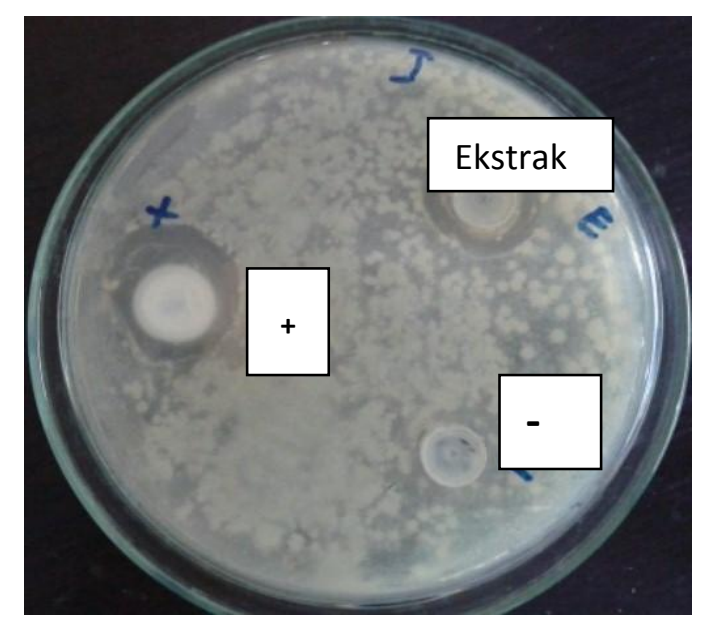

Gambar 1. Zona hambat yang terbentuk pada media MHA
Tabel 1. Perbandingan diameter zona hambat terhadap bakteri Porphromonas gingivalis

\begin{tabular}{lccc}
\hline Cawan & \multicolumn{3}{c}{ Diameter zona hambat } \\
Petri & $\begin{array}{c}\text { Ekstrak } \\
\text { Padina } \\
\text { australis } \\
\text { Hauck }\end{array}$ & $\begin{array}{c}\text { Metronidazole } \\
\text { (kontrol +) }\end{array}$ & $\begin{array}{c}\text { Akuades } \\
\text { (kontrol -) }\end{array}$ \\
\hline I & 18,5 & 21,5 & \\
II & 17,5 & 20,0 & 0 \\
III & 18,0 & 22,0 & 0 \\
IV & 18,5 & 20,0 & 0 \\
V & 18,5 & 20,0 & 0 \\
Total & 91,0 & 103,5 & 0 \\
Rerata & 18,2 & 20,7 & 0 \\
\hline
\end{tabular}

\section{BAHASAN}

Hasil pengamatan yang dilakukan untuk lima kali pengulangan menunjukkan adanya zona hambat yang terbentuk di sekitar sumur yang diberi ekstrak Padina australis Hauck. Zona hambat ekstrak Padina australis Hauck yang tertinggi ditunjukkan pada pengulangan ke I yakni $18,5 \mathrm{~mm}$, ke IV $18,5 \mathrm{~mm}$, dan ke V yakni sebesar 18,5 mm. Zona hambat terkecil ditunjukkan pada pengulangan ke II yakni sebesar 17,5 mm. Rerata diameter zona hambat di sekitar sumur yang dihasilkan ekstrak Padina australis Hauck sebesar $18,2 \mathrm{~mm}$.

Hasil pengukuran diameter zona hambat dapat digolongkan berdasarkan kategori kekuatan zona hambat oleh David dan Stout yaitu: tidak ada zona hambat, zona hambat lemah $(<5 \mathrm{~mm})$, zona hambat dengan kekuatan sedang $(5-10 \mathrm{~mm})$, zona hambat kuat (11-20 mm), dan zona hambat sangat kuat $(21-30 \mathrm{~mm}) .{ }^{8}$ Ekstrak Padina australis Hauck memiliki kekuatan zona hambat yang tergolong kategori kuat dalam menghambat pertumbuhan bakteri Porphyromonas gingivalis. Bila dibandingkan dengan zona hambat yang berada di sekeliling metronidazole, diameter zona hambat ekstrak Padina australis Hauck lebih kecil sedangkan pada sumur yang diberi akuades tidak menunjukkan zona hambat. Metronidazole juga memiliki aktivitas antibakteri terhadap bakteri anaerob, termasuk Bacteroides.

Metronidazole secara selektif diserap 
oleh bakteri aerob dan protozoa sensitif. Mekanisme metronidazole membunuh bakteri yaitu dengan masuk ke dalam mikroorganisme tersebut dan bereduksi menjadi polar kemudian menghambat sintesis asam nukleat dan mengakibatkan kematian sel bakteri. ${ }^{9}$

Zona hambat yang terbentuk di sekitar sumur ini disebabkan oleh aktivitas biologis dari senyawa bioaktif yang terkandung dalam Padina australis Hauck. Berdasarkan skrining fitokimia ekstrak etanol Padina australis Hauck yang diperoleh dari pantai Molas Sulawesi Utara, ekstrak Padina australis Hauck positif mengandung senyawa bioaktif di antaranya alkaloid, saponin, fenolik, steroid, dan tanin. ${ }^{10}$ Semakin lebar zona hambat yang terbentuk menandakan semakin kuat senyawa bioaktif yang terkandung dalam Padina australis Hauck dalam menghambat pertumbuhan bakteri.

Mekanisme alkaloid pada Padina australis Hauck sebagai antibakteri yakni dengan cara merusak komponen penyusun peptidoglikan pada sel bakteri, sehingga lapisan dinding sel tidak terbentuk secara utuh dan menyebabkan kematian pada sel tersebut. ${ }^{11}$ Mekanisme senyawa saponin menghambat pertumbuhan bakteri dengan menurunkan tegangan permukaan sehingga mengakibatkan senyawa intraseluler akan keluar. ${ }^{12}$ Senyawa golongan fenol yang dimiliki tumbuhan mampu merusak membran sel, mendenaturasi protein sehingga dinding sel mengalami kerusakan karena penurunan permeabilitas. ${ }^{13}$ Tanin terbentuk dari senyawa fenol yang berkaitan atau bergabung dengan senyawa fenol lainnya sehingga membentuk polifenol yang pada akhirnya terbentuk senyawa tanin.

Mekanisme steroid merusak membran plasma sel mikroba yang menyebabkan bocornya sitoplasma keluar sel sehingga menyebabkan kematian sel bakteri tersebut. $^{14}$ Zona hambat dalam penelitian ini menunjukkan bahwa ekstrak Padina australis Hauck memiliki efek antibakteri pada bakteri Porphyromonas gingivalis namun zona hambat ekstrak Padina australis Hauck lebih kecil dibandingkan metronidazole yang menunjukan diameter zona hambat yang lebih besar karena memiliki spektrum yang lebih luas dalam menghambat bakteri. Ekstrak Padina australis Hauck lebih kecil bukan berarti kurang aktif kemungkinan tidak terdeteksi pada konsentrasi sampel uji yang digunakan, karena kondisi lingkungan, media bakteri uji, suhu, waktu inkubasi, dan umur bakteri juga memengaruhi lebar zona hambat yang terbentuk pada tiap perlakuan konsentrasi ekstrak. ${ }^{15}$ Menurut Hermawan ${ }^{16}$ interpretasi daerah hambatan pertumbuhan antimikroba mengacu pada standar umum yang di keluarkan Departemen Kesehatan tahun 1988, disebutkan bahwa mikroba dikatakan peka terhadap antimikroba asal tanaman bila mempunyai ukuran diameter daya hambatan sebesar 12-24 mm.

Hasil penelitian ini menunjukkan bahwa ekstrak Padina australis Hauck memiliki kandungan senyawa bioaktif yang dapat digunakan sebagai antibakteri untuk menghambat pertumbuhan bakteri Porhyromonas gingivalis, sebagai antibiotik alami dalam pencegahan dan penanggulangan periodontitis, dan sebagai campuran bahan kandungan obat untuk periodontitis atau campuran larutan obat kumur.

\section{SIMPULAN}

Ekstrak Padina australis Hauck memiliki aktivitas antibakteri dalam menghambat pertumbuhan bakteri Porphyromonas gingivalis dengan zona hambat $18,2 \mathrm{~cm}$ yang tergolong katagori kuat.

\section{SARAN}

Perlu dilakukan penelitian lebih lanjut mengenai uji daya hambat antibakteri ekstrak Padina australis Hauck terhadap bakteri Porphyromonas gingivalis dengan berbagai konsentrasi kepekatan ekstrak sehingga dapat diketahui nilai Minimum Inhibitory Concentration (MIC) ekstrak tersebut terhadap Porphyromonas gingivalis. 
DAFTAR PUSTAKA

1. Wahyukundari MA. Perbedaan kadar matrix metalloproteinase- 8 setelah scaling dan pemberian tetrasiklin pada penderita periodontitis kronis. Jurnal PDGI. 2008;58(1):1-6.

2. Carranza F, Newman M, Tekai H, Klokkevold P. Clinical Periodontology (11th ed). Philadelphia: WB Saunders, 2008; p. 495-9.

3. Yilmaz O. The chronicles of Porphyromonas gingivalis: the microbium, the human oral epithelium and their interplay. Microbiolgy. 2008;154:289.

4. Ernawati DS, Maduratna E. Infeksi dan imunitas Phorpyromonas gingivalis. Majalah Kedokteran Gigi Universitas Airlangga. 2001;34:239-41.

5. Singkoh MFO. Aktivitas antibakteri ekstrak alga laut Caulerpa racemosa dari perairan pulau Nain. Jurnal Perikanan dan Kelautan Tropis. 2011;VII(3):123-7.

6. Aslant LM. Budidaya Rumput Laut. Yogyakarta: Kanisius,1998; p. 13-5.

7. Holdt SL, Kraan S. Bioactive compounds in seaweed: functional food applications and legislation. J Appl Phycol. 2011;23(3):543-9

8. Davis WW, Stout TR. Disc plate method of microbiological antibiotic assay. Appl Microbiol. 1971;22(4):659-65.

9. Katzung BG, Masters SB, Trevor AJ. Farmako Dasar dan Klinik (12th ed). Jakarta: EGC, 2012; p. 1009.

10. Zen NAM, Queljoe ED, Singkoh M. Uji bioaktifitas ekstrak padina australis dari pesisir pantai Molas Sulawesi Utara terhadap bakteri Staphylococcus epidermidis. Jurnal pesisir dan laut tropis. Universitas
Samratulangi. 2015; (1):2: p. 34-5.

11. Darsana I, Besung I, Mahatmi H, Potensi daun Binahong (Anredera cordifolia) dalam menghambat pertumbuhan bakteri Escherichia Coli secara in vitro. Indonesia Medicus Veterinus. 2012;(3):1: p.337-51.

12. Nuria MCA, Faizatun, Sumantri. Uji antibakteri ekstrak etanol daun jarak pagar (Jatropha Curcas L) terhadap bakteri Staphylococcus Aureus ATCC 25923, Escherichia Coli ATCC 25922 dan Salmonella Typhi ATCC 1408. Mediagro. 2009;5(2)26-37.

13. Makar HPS. Effect and fate of tannins in ruminat animals, adaptation to tannins and strategies to overcome detrimental effects of feeding tannin rich feeds. Animal Production and Health Section, Joint FAO/IAEA Division. Vienna, Austria: International Atomic Energy Agency, 2003; p. 241-56.

14. Putra INK. Study daya antimikroba ekstrak beberapa bahan tumbuhan pengawet nira terhadap mikroba perusak nira serta kandungan senyawa aktifnya [Disertasi]. Malang: Program Pasca Sarjana Universitas Brawijaya; 2007.

15. Rajendra CE, Gopal S, Mahaboob Ali, Yashoda SV, Manjula $M$. Phytocemical screening of the Rhizome of Kaempferia galanga. IJPPR. 2011;3(3):61-3.

16. Hermawan AH, Eliyani, Tyasningsih W. Pengaruh ekstrak daun sirih (Piper betle L.) terhadap pertumbuhan Staphylococus aureus dan Esherichia coli dengan metode difusi disk [Artikel ilmiah]. Surabaya: Universitas Airlangga, 2007; p.1-9. 